\title{
Nuclear energy policy issues in Japan after the Fukushima nuclear accident
}

\author{
Tatsujiro Suzuki
}

\section{Abstract}

The Fukushima nuclear accident of 11 March 2011 was a turning point for Japan's nuclear energy and overall energy policy. The biggest impact was the loss of public trust, not only in relation to nuclear safety, but also overall energy policy. More than five years after the catastrophe, this is still the case and more than 80 per cent of the public want to phase out nuclear power eventually. In short, the effects of the accident are not over yet. On 11 April 2014, the Japanese government adopted a new national Strategic Energy Plan declaring its intention to reduce dependence on nuclear energy while considering it as one of the important base-load electricity sources. Regardless of the future of nuclear energy, there are five key policy issues that Japan needs to face: spent fuel management, plutonium stockpile management, radioactive waste disposal, human resources management, and restoring public trust. This chapter discusses those five critical issues and possible policy alternatives that Japan should pursue. 


\section{Introduction}

The Pacific Ocean earthquake and resulting tsunamis that struck the Tohoku District and Fukushima Daiichi and Daini nuclear power stations at 14.46 on 11 March 2011 (3/11) were followed by a nuclear accident unprecedented in both scale and time frame. Since then, 3/11 has become a historic day for all nuclear experts to remember not only in Japan but also in the rest of the world. Although the earthquake occurred in 2011, the effects of the accident continue. About 100,000 evacuated residents in Fukushima still live in temporary housing and are uncertain as to when they will be able to return to their original hometowns. Although conditions at the Fukushima power stations have improved, it will take more than 40 years to remove melted fuel debris from the site and decommission the plant. We need to draw lessons based on the knowledge and information available to ensure the safety of existing nuclear facilities as much as possible, and to understand potential implications for future nuclear energy policy.

This chapter summarises the current status, both on-site and off-site, of the Fukushima Daiichi nuclear power plant, and reviews possible impacts on Japan's energy policy as well as on global nuclear power development. The chapter identifies key policy issues that are important regardless of the future direction of nuclear power in Japan.

\section{Current status and future prospects of the Fukushima Daiichi nuclear power plant and the environment}

On 12 June 2015, the Inter-Ministerial Council for Contaminated Water and Decommissioning Issues (2015) published an updated 'Mid-andlong-term roadmap towards the decommissioning of TEPCO's Fukushima Daiichi nuclear power station'. The report emphasised 'risk reduction', implying that the decommissioning process still poses significant risk to workers and the public. It also delayed the first phase (removing spent fuel from the storage pools of Units 1-3) by more than three years.

The Tokyo Electric Power Company (TEPCO), the owner and operator of the Fukushima nuclear power plant, is responsible for decommissioning the plant. It has been struggling with the storage of a huge and increasing amount of contaminated water (roughly 400 tonnes per day), some 
of which, it is suspected, has leaked into the sea. In order to contain the contaminated water, TEPCO and the Ministry of Economy, Trade and Industry (METI) decided to install a so-called 'frozen wall' to stop water flowing in and out of the site. The wall is almost complete, but the Nuclear Regulatory Authority concluded that its effectiveness is limited and that alternative methods (such as pumping out underground and contaminated water) need to be continued (Asahi Shimbun 2016).

Contaminated water is just one of the unprecedented challenges that TEPCO and METI face. The roadmap for decommissioning Fukushima Daiichi estimates that it will take at least 30 to 40 years to complete decommissioning. The first stage involves removal of the spent fuel from the pools in all four units (in two to three years), the second stage involves removal of the melted core debris from Units 1-3 (in at least 10 years), and the third stage encompasses decontamination of the whole plant (in 30 to 40 years). Removal of spent fuel (1,331 spent fuel assemblies and 202 unirradiated fuel assemblies) from Unit 4's storage pool was successfully completed on 22 December 2014. Operations to remove spent fuel from Units 1-3 are now underway. For removal of the melted cores, the information available on melted debris is very limited and no one is sure where they are or what form they now take. It is not possible to get close to the reactor buildings of Units 1-3 due to high radiation, and it is necessary to develop remote-control equipment or sophisticated, radiation-resistant robots.

On 1 April 2014, TEPCO established a new company, the Fukushima Daiichi Decontamination and Decommissioning Engineering Company, as a dedicated institution to manage this huge, complex, and challenging operation. An International Research Institute for Nuclear Decommissioning was also established in August 2013 by METI, TEPCO, and other interested parties, including nuclear vendors and the Japan Atomic Energy Agency (JAEA). The institute's purpose is to promote necessary research and development efforts for decommissioning in general, but especially for the Fukushima Daiichi nuclear reactors. However, there are still concerns about a lack of transparency and independent oversight in regard to the whole decommissioning process. The Japan Atomic Energy Commission (JAEC) recommended that the government should establish an independent (third-party) organisation with overseas experts as members to assess and audit the entire measures in order to maximise transparency (JAEC 2012b). However, such an independent organisation has not been established by the government. 


\section{Decontamination and reconstruction of evacuated zones}

There are three different levels of evacuated zones designated by the government, depending on the level of monitored radiation levels: a 'nonreturn' zone (above 50 milliSieverts $(\mathrm{mSv})$ per year); a 'preparation for return' zone (below $50 \mathrm{mSv}$ per year and above $20 \mathrm{mSv}$ per year); and a 'possible to return' zone (below $20 \mathrm{mSv}$ per year). Due to natural radiation decay and decontamination efforts, more areas are now designated as 'possible to return' zones. On 31 August 2016, the government announced that some of the 'non-return' zones would be designated as 'recovering centres' and that life infrastructure would be re-established so that people could return soon (Recovery Council, Nuclear Accident Emergency Response Headquarters 2016). However, the criteria of $20 \mathrm{mSv}$ per year has been a source of public debate as it is much higher than the $5 \mathrm{mSv}$ per year level that was the evacuation criteria for the Chernobyl accident five years after that accident.

The issue of returning to the hometown is connected to the compensation issue. Under current rules, once the town is no longer considered as an evacuated zone, citizens are no longer eligible for compensation. More importantly, there is not enough public participation in the decisionmaking process, which will lead to a loss of public trust, as discussed below.

\section{Loss of public trust}

On 24 February 2015, TEPCO (2015) issued a press release stating that the source of high radiation levels in one of its drains originated from a puddle of rainwater that had accumulated on the rooftop of Unit 2 at the Fukushima Daiichi nuclear power station. The drain leads to open seawater. It was thus suspected that contaminated water may have leaked into the sea, although TEPCO found 'no increase in radioactivity' in the seawater in the area.

This illustrates just one episode in a series of many adverse events in Japan's nuclear industry that have been reported over the past four years. However, this particular incident was worse than usual because TEPCO was aware of the high level of radioactivity in the drain but failed to notify the Nuclear Regulation Authority or the local government. It was also 
very bad timing. After long negotiations with the local fishing industry, TEPCO was about to release some of the accumulated radioactive groundwater, which had been cleaned through a water treatment process, into the Pacific Ocean. On 25 February 2015, the local fishing industry association criticised TEPCO, with Hiroyuki Sato, the chairman of the Soma-Futaba Fisheries Cooperative Association, stating that 'trust has been lost'.

Lack of trust is a fundamental problem that underlies the challenges facing Japan's nuclear industry since the Fukushima disaster. The public has lost faith in nuclear safety regulation. Faith has not been fully restored even though a newly independent Nuclear Regulation Authority was established in 2012, and much tougher regulatory standards were introduced. According to poll results, the proportion of the public that want to shut down all nuclear power plants immediately increased from 13.3 per cent in June 2011 to 30.7 per cent in March 2013. The same polling data also suggested that about 80 per cent of the public still believed that serious nuclear accidents would occur again in Japan (Hirose 2013).

In polling undertaken in August 2014, the proportion of the public who oppose restarting the existing reactors rose to 56 per cent, an increase of 4 percentage points from previous polling on this question. The same poll indicated that 61 per cent of the public were willing to accept higher electricity prices if existing nuclear power plants remained closed (Nihon Keizai Shimbun 2014). Hirose's (2013) polling also suggested that government agencies were considered to be the 'most untrustworthy' organisations of those that were listed. This loss of trust is the most serious challenge that nuclear policymakers and the nuclear industry now face in Japan. Six years after the accident, it has not been addressed adequately.

Two recent important policy developments have occurred that have further eroded public trust. First, on 20 December 2016, the TEPCO Reform Committee (2016) published a new report concerning TEPCO reform, in which it outlined new estimates for total accident-related costs and its financing scheme. The total estimated cost of the accident is now about $¥ 22$ trillion (US $\$ 200$ billion), which is two times higher than the previous estimate. The estimated costs of each item are as follows: Fukushima Daiichi decommissioning (¥8 trillion), compensation costs ( $¥ 8$ trillion), and the decommissioning of contaminated land ( $¥ 6$ trillion). The report also announced that TEPCO should bear about $¥ 16$ trillion 
of the cost, but that the rest should be financed by other electricity companies— $¥ 4$ trillion from new and conventional utilities—and $¥ 2$ trillion from the government.

Second, on 21 December 2016, the Cabinet Ministers' Meeting on Nuclear Energy Policy released two policy documents: 'Basic policy of fast reactor development' and 'Government policy on the fast reactor prototype reactor "Monju"' (Cabinet Ministers' Meeting on Nuclear Energy 2016a, 2016b). These policy documents emerged in response to the 'Recommendation by the Nuclear Regulatory Authority on Monju' issued in November 2015, which recommended that the government must find an alternative operating/managing institution to the JAEA as the JAEA was judged to be incapable of operating Monju (NRA 2015). The documents stated that the government had decided to decommission Monju from 2017, while fast reactor development would continue without Monju. The government also renewed its commitment to build a 'demonstration fast reactor' and to achieve 'future commercialisation of fast reactor'. But this policy decision was based on a statement made by a series of closed meetings, called 'Fast reactor development meeting', consisting of the JAEA, METI, the Ministry of Education, Culture, Sports, Science and Technology, the Federation of Electric Power Companies (FEPC), and Mitsubishi Heavy Industry. Without open debate and a thorough review of the Monju project, the credibility and feasibility of a fast reactor program is now in serious doubt.

\section{Possible impacts on Japan's energy policy}

The economic impact of shutting down nuclear power plants is also significant. According to a study carried out by the Institute of Energy Economics, Japan (2013), about ¥3.6 trillion (US\$36 billion) of extra payments were made because of the shutdown of nuclear power plants during Fiscal Year 2011 and Fiscal Year 2012 (the Japanese fiscal year starts in April and ends in March), while energy demand decline contributed to about $¥ 1.2$ trillion (US $\$ 12$ billion) of savings during the same period. In addition, carbon dioxide emissions in 2012 increased by about 70 million tonnes, that is, an increase of about 5.8 per cent from 2011 levels, which was roughly equal to the emission increase in the Middle Eastern region or India alone in 2012 (IEA 2013). 
On 11 April 2014, the new Strategic Energy Plan was adopted by the Japanese Cabinet (METI 2014a). The plan stated that the government would not only decrease its dependence on nuclear energy as much as possible, but also that nuclear power should be used as an important baseload energy source and thus the necessary level of nuclear energy should be maintained.

The METI Advisory Council set up one working group to determine the future energy mix targeted for 2030, and another working group to re-examine the generation cost of nuclear power compared with other power sources. On 5 April 2015, it was reported that METI's new cost estimate for newly built nuclear power would be about ¥1 per kilowatt hour (kWh) more expensive than the $¥ 8.9$ per kWh previously estimated by the government in 2012, but still believed to be less expensive than newly built fossil fuel power plants (Nihon Keizai Shimbun 2015). On 7 April 2015, METI stated that so-called 'base-load' electricity should supply about 60 per cent of total power generation, with nuclear power, coal, and geothermal power being part of such base-load power sources. In July 2015, METI published its new long-term energy outlook based on its Strategic Energy Plan of 2014 (METI 2015b). According to the outlook, the share of nuclear energy in total power generation will be around 2022 per cent, which is a slight decline from 2010 (26 per cent), and the share of renewable energy will be around 22-24 per cent. Maintaining the nuclear share of 20-22 per cent is likely to require extension of the 40-year lifetime operating period of current nuclear power plants, or the building of new nuclear power plants. This policy has been criticised as being inconsistent with the goal of 'reducing the dependency on nuclear power as much as possible' (Asahi Shimbun 2015a). The Ministry of Environment also published its future energy mix plan, suggesting that the share of renewable energy could be increased to $24-35$ per cent by 2030 (Asahi Shimbun 2015b).

\section{Policy issues and challenges regardless of future directions of nuclear power in Japan}

Although Japan's future energy policy is still under discussion, certain important issues need to be overcome: spent fuel management, plutonium stockpile management, high-level waste disposal, securing human resources, and restoring public trust. 


\section{Spent fuel management}

Even before the Fukushima accident, the question of the management of accumulating spent fuel on-site at nuclear power plants was a major policy issue for nuclear utilities and the government. By the end of 2011, about 17,000 tonnes of spent fuel were in storage, out of which about 14,000 tonnes were at nuclear power plant sites and 2,900 tonnes were at the Rokkasho reprocessing plant. The total spent fuel pool storage capacity at nuclear power plant sites is about 20,630 tonnes, and this is roughly 70 per cent full (Takubo and von Hippel 2013). For some reactor sites, the pool will be full within a few years if reactors restart operations. The Rokkasho reprocessing plant, with planned capacity to reprocess 800 tonnes of spent fuel per year, has only one storage pool with a 3,000 tonne capacity. The plant is currently shutdown after a period of hot testing and the repair of vitrification equipment, and it is not clear when it will start commercial operation, due to new regulatory standards. Since the storage pool is almost full, unless the plant starts commercial operation, it may not be able to accept further spent fuel.

Another option is an 'away-from-reactor' centralised storage facility at Mutsu city, which is also under construction. Its capacity is 5,000 tonnes but it is not yet fully operational and will accept only spent fuel from TEPCO and the Japan Atomic Power Company. Safe and secure dry cask storage on-site is technically possible, as proven at the Fukushima Daiichi site, where dry casks loaded with spent reactor fuel withstood the earthquake and tsunami without significant damage, and at the Tokai Daini nuclear power plant site. But local communities at nuclear power plant sites are not in favour of accepting further spent fuel storage on-site.

In short, finding additional storage capacity (possibly dry cask storage) is a top priority issue for nuclear utilities and the government, in order to increase the flexibility of spent fuel management, as uncertainty regarding reprocessing still remains.

\section{Plutonium stockpile management}

The basic policy for spent fuel management in Japan has been (and still is) 'reprocessing and recycling plutonium' for energy use. Since plutonium can also be used to manufacture nuclear bombs, the JAEC introduced a 'no plutonium surplus' policy from 1991, and strengthened its policy in 2003 by introducing new guidelines to improve its transparency 
when the Rokkasho commercial reprocessing plant was expected to start operations. According to the guidelines, utilities are expected to submit a 'plutonium usage plan' annually before they reprocess and recover plutonium. In short, this is intended to ensure that Japan will not possess plutonium without plans for its use. However, in reality, the plutonium usage program (recycling as mixed-oxide fuel into existing reactors and fast breeder reactors in the future) has been delayed significantly. As a result, by the end of 2015, Japan possessed about 48 tonnes of separated plutonium (10.8 tonnes in Japan, and 37.1 tonnes in France and the UK where Japan has commercial reprocessing contracts; see Table 1.1) (JAEC 2016). This is the largest stockpile among non-nuclear weapon states and could increase further if the Rokkasho reprocessing plant starts operation, and if its recycling program into 15-18 reactors as currently planned does not smoothly move ahead. As a result, if the Rokkasho plant starts operating, Japan's plutonium stockpile is likely to grow (Takubo and von Hippel 2013).

Table 1.1 Japan's stockpile of separated plutonium

\begin{tabular}{|l|c|c|}
\hline & $\begin{array}{c}\text { Stockpile at the end } \\
\text { of 2014 (kg) }\end{array}$ & $\begin{array}{c}\text { Stockpile at the end } \\
\text { of 2015 (kg) }\end{array}$ \\
\hline Stock in Japan (Pu total) & & \\
\hline Reprocessing plants & 4,322 & 4,126 \\
\hline Mixed-oxide fuel plant & 3,404 & 3,596 \\
\hline Stored at reactors & 3,109 & 3,109 \\
\hline Sub-total (fissile plutonium) & $10,835(7,310)$ & $10,832(7,307)$ \\
\hline Stocks in Europe (Pu total) & & \\
\hline United Kingdom & 20,696 & 20,868 \\
\hline France & 16,278 & 16,248 \\
\hline Sub-total: Pu total (fissile plutonium) & $36,974(24,511)$ & $37,115(24,574)$ \\
\hline Total (fissile plutonium) & $47,809(31,821)$ & $47,947(31,881)$ \\
\hline
\end{tabular}

* Fissile plutonium (Pu 239 and Pu 241) is typically about 60 per cent of total plutonium, which includes non-fissile isotope of plutonium (Pu 240 and Pu 242).

$\mathrm{Pu}=$ plutonium

Source: JAEC (2016).

Meanwhile, due to heightened concern over nuclear proliferation and nuclear security, international attention on Japan's plutonium stockpile is also increasing. For example, the US-Japan Nuclear Working Group of the Maureen and Mike Mansfield Foundation published its recommendations on nuclear energy policy for Japan: 
The disposition of Japan's sizeable plutonium stockpile is an outstanding issue that must be addressed regardless of whether or not Japan decides to move forward with nuclear power ... Absent a credible strategy for reducing Japan's plutonium stockpile, nonproliferation and security concerns will grow over time, undermining Japan's international leadership on nuclear nonproliferation (US-Japan Nuclear Working Group 2014: 4).

In order to reduce such concern and to minimise proliferation and nuclear security risks, Japan may need to produce a new plutonium management plan. I propose three new principles for plutonium management in Japan:

1. Demand comes first: Reprocessing should take place only when plutonium demand (use) is specified.

2. Stockpile reduction: Matching demand/supply is not good enough. The existing stockpile should be reduced before further reprocessing.

3. Flexible plan: The current plutonium use plan (mixed-oxide recycling in 16-18 units) is no longer certain. Other options (plutonium ownership transfer, disposition as waste, and so on) need to be pursued. Such options should minimise cost, transportation, and time required for disposal (Suzuki 2013).

In addition, a multilateral approach to managing nuclear fuel cycle facilities can be a good way to improve international confidence in Japan's nuclear fuel cycle program. One such idea is to put both enrichment and reprocessing facilities under international control (Diesendorf 2014). In the future, this approach could even be applied to facilities in other countries in the region, including China and North Korea.

\section{High-level radioactive waste disposal}

Like many other countries, Japan has not found a final repository site for high-level radioactive waste (HLW). Since 2000, when the Law on Final Disposal of Specified Radioactive Waste (i.e. vitrified HLW) was passed and the Nuclear Waste Management Organisation was established as the principal implementation institution for final disposal, all efforts to find even a single candidate for possible investigation did not succeed. Japan's approach was to wait for local communities to volunteer as candidates; only one town (Toyo-town) volunteered, but later cancelled the request due to strong public opposition. In 2010, the JAEC asked the Science Council of Japan for their advice on how to improve public communication on HLW, and the Science Council published its response in 2012 (Science Council of Japan 2012). The report recommended a fundamental reform 
of Japan's HLW disposal policy. In particular, it was recommended that '(long term) temporary storage' be used instead of 'geological disposal', for which it argued that scientific knowledge is still too uncertain to commit to geological disposal in Japan.

The JAEC responded with its own policy statement in December 2012 (JAEC 2012d). The JAEC agreed with the Science Council that the current HLW disposal program needed to be reviewed, but maintained the basic conclusion of its advisory committee report that was published in 1998, which recommended 'geological disposal' as the most appropriate policy option under current circumstances. Still, the JAEC also agreed with the Science Council that constant review of the program is necessary and 'retrievability' and 'reversibility' should be clearly integrated into the disposal program. Further, the JAEC also recommended that the government 'establish an independent and functionally effective third party organization to provide suitable advice to the government and related parties in time'.

METI set up two working groups to review the HLW disposal program. One was to examine the whole process and programs including public participation, and the other was to review scientific knowledge on HLW disposal in Japan especially after 3/11. Based on its findings (METI 2014b), a 'Basic plan for final disposal of specified radioactive waste' was adopted by the Cabinet on 22 May 2015 (METI 2015a). The new plan now places stronger responsibility with the government and introduced some flexibility, including the concept of 'retrievability' and 'reversibility'. Still, the future of the HLW disposal program is very uncertain.

The Science Council of Japan published a report to follow up its 2012 report, re-emphasising the importance of a 'consensus building process' for HLW disposal and proposing the creation of a 'national people's conference on radioactive waste' (Science Council of Japan 2015). The Science Council proposed to use a period established by the 'temporal storage' (not 'interim storage', which assumes that the final decision on HLW disposal has been made) for gaining national consensus. Whether such a proposal will be accepted by the government remains to be seen. 


\section{Securing human resources and research and development}

Since the future prospects of nuclear power have become uncertain, it is likely that attracting young and capable talent to nuclear energy fields may become difficult. Further, there is an emerging demand for new tasks such as the decommissioning of Fukushima reactors. Therefore, it is important to secure human resources to meet such new and challenging tasks in the coming decades. Research and development programs also need to be re-examined to meet new challenges and to provide future human resources. In order to meet such challenges, the JAEC published policy statements on human resources and on research and development in 2012 (JAEC 2012c, 2012e).

For human resource management, the JAEC recommended, among other things, to draw a 'human resource demand/supply map'- 'the related government agencies and demand side, including the nuclear industry, [should] clarify when, in what areas and how much manpower is required based on operational plans' (JAEC 2012c). This cannot be done by the government agencies, but should be undertaken by related industry organisations as they have better knowledge and data. Other important recommendations included education based on lessons learned from the Fukushima accident, providing new education opportunities for mid-career experts, enhancing human resource development for nuclear safety, security, and safeguards, providing incentives for nuclear businesses to maintain human resources, securing human resources for maintaining the operation of domestic nuclear power plants, and human resource development for international deployment of nuclear energy and technology.

\section{Restoring public trust}

Last, but not least, public trust must be restored. As noted above, the loss of public trust in the government's handling of nuclear energy policy is one of the biggest consequences of the Fukushima accident. The JAEC issued a policy statement on this issue in 2012 (JAEC 2012a), and listed four basic principles for restoring public confidence. 


\section{Accountability}

First, it is important that the individuals/organisations tackling such challenges explain their mission to the public — what they do, and why and how they do it. Such individuals/organisations should be aware of their primary responsibility to seek solutions to challenges and manage risks in the public interest, and be accountable for their plans and the results of their actions. They have an obligation to continuously explain to the public how their actions fulfill their responsibilities and their commitment to public well-being and safety.

\section{Correct information disclosure}

Second, it is important to remember that these explanations should be provided based on sufficient and correct information to the public on a timely basis. For example, in discussing a plant operator's actions for nuclear power safety, we should carefully explain the nature of the threat facing a facility, the operator's target, and how it intends to reach the target. In doing so, explaining by using comparisons with other facilities is acceptable but must be done carefully. Evaluations should be made including all relevant factors, including costs, environmental impacts, and stability, and comparison based on one point alone may be inappropriate, even if accurate. However, we should also note that speed is sometimes more important than accuracy. In that case, details should immediately be provided about what has happened and why, and what can be expected to happen in the future, while explaining uncertainties in such information and the range of possible outcomes.

\section{Transparency/fairness and public involvement in decision processes}

Third, it is important to design fair decision-making processes, as the basis for administrative decisions, and, in making the process open, to provide opportunities for public participation in the process. In this case, the parties concerned should deeply appreciate that securing transparency means the public can view the decision-making process, access information, and provide input into these processes. Based on this acknowledgment, the greater the public interest in a decision, the more carefully the public should be involved at the earliest possible stage before decisions are made. Organisations involved should strive to give the public opportunities to express their views. 
Further, administrative bodies should establish verifiable decision-making processes, with full and accessible documentation: from the creation of administrative documents, and hearings from experts, interested parties and the public, to final decision-making.

\section{Easy-to-understand explanations}

Fourth, public explanations should be clear and plain, with accuracy a prerequisite. It is often noted that if the public cannot understand information released, it cannot be considered transparent, even if it is believed that transparency is attained in doing so. It is not easy to ensure material is both accurate and comprehensible, but court decisions have long been written in normal Japanese. Administrative bodies must not forget to check the processes of creating documents and preparing explanations from this perspective, continuously educating and training themselves in this area.

\section{Conclusion}

Nuclear energy policy after 3/11 needs to be changed to reflect lessons learned from the Fukushima accident and the different priorities and tasks required after the Fukushima accident, such as the decommissioning of the Fukushima site and restoring lives and livelihoods for people in Fukushima and other affected areas; enhancing safety and security, spent fuel management, plutonium stockpile management, waste disposal, and human resource development; and, most of all, restoring public trust. The Japanese government should also initiate a national debate to re-examine the risks and benefits of nuclear energy involving various stakeholders and civil society. Establishing an independent commission to conduct a comprehensive, non-biased assessment of nuclear energy policy would be desirable. These are necessary changes regardless of the future directions of nuclear energy in Japan.

\section{References}

Asahi Shimbun, 2015a. Reduction target for greenhouse gases set at 25\% at 2030: Government's draft plan submitted. 24 April.

Asahi Shimbun, 2015b. Share of renewable energy will be around mid 20\%' for energy mix in 2030, METI says. 8 April. 
Asahi Shimbun, 2016. 'Effectiveness of the wall is limited', the Nuclear Regulatory Authority concluded. 27 December.

Cabinet Ministers' Meeting on Nuclear Energy, 2016a. Kosokuro Kaihatsu no Hoshin [Basic policy of fast reactor development]. 21 December. www.cas.go.jp/jp/seisaku/genshiryoku_kakuryo_kaigi/ pdf/h281221_siryou1.pdf (accessed 23 January 2017).

Cabinet Ministers' Meeting on Nuclear Energy, 2016b. Monju no Toriatsukai ni Kansuru Seifu Houshin [Government policy on the fast reactor prototype reactor 'Monju']. 21 December. www.cas.go.jp/ jp/seisaku/genshiryoku_kakuryo_kaigi/pdf/h281221_siryou2.pdf (accessed 23 January 2017).

Diesendorf, Mark, 2014. Sustainable Energy Solutions for Climate Change. Sydney: UNSW Press.

Hirose, Hirotada, 2013. Genshiryoku Hatsuden wo meguru yoron no henka [Changes of public opinion regarding nuclear power]. Presentation to the Japan Atomic Energy Commission regular meeting, 17 July. www.aec.go.jp/jicst/NC/iinkai/teirei/siryo2013/ siryo27/siryo2.pdf (accessed 23 January 2017).

IEA (International Energy Agency), 2013. Redrawing the energy-climate map. 10 June.

Institute of Energy Economics, Japan, 2013. Dengen Betsu Kosuto Jisseki Hyoka to Denki Jigyo Zaimu he no eikyo [Assessment of power generation cost based on actual data and its impacts on financial performance of electric utility companies]. Presentation to the Japan Atomic Energy Commission, 20 August. www.aec.go.jp/jicst/NC/ iinkai/teirei/siryo2013/siryo31/siryo3.pdf (accessed 27 February 2017).

Inter-Ministerial Council for Contaminated Water and Decommissioning Issues, 2015. Mid-and-long-term roadmap towards the decommissioning of TEPCO's Fukushima Daiichi nuclear power station. 12 June. www.meti.go.jp/english/earthquake/nuclear/ decommissioning/pdf/20150725_01b.pdf (accessed 23 January 2017).

JAEC (Japan Atomic Energy Commission), 2012a. Efforts to build public confidence. 25 December. www.aec.go.jp/jicst/NC/about/ kettei/121225-2_e.pdf (accessed 23 January 2017). 
JAEC (Japan Atomic Energy Commission), 2012b. Progress of medium- and long-term efforts to decommission Fukushima Daiichi NPP of TEPCO. 27 November. www.aec.go.jp/jicst/NC/about/ kettei/121127-1_e.pdf (accessed 27 February 2017).

JAEC (Japan Atomic Energy Commission), 2012c. Promotion of measures to secure and develop human resources for nuclear energy. 27 November. www.aec.go.jp/jicst/NC/about/kettei/121127-2_e.pdf (accessed 23 January 2017).

JAEC (Japan Atomic Energy Commission), 2012d. Renewing approaches to geological disposal of high-level radioactive waste (HLW). 18 December. www.aec.go.jp/jicst/NC/about/kettei/121218_e.pdf (accessed 23 January 2017).

JAEC (Japan Atomic Energy Commission), 2012e. Research and development on nuclear power in the future should be. 25 December. www.aec.go.jp/jicst/NC/about/kettei/121225-1_e.pdf (accessed 23 January 2017).

JAEC (Japan Atomic Energy Commission), 2016. The status report of plutonium management in Japan - 2015. 27 July. www.aec. go.jp/jicst/NC/iinkai/teirei/siryo2016/siryo24/siryo1_e.pdf (accessed 23 January 2017).

METI (Ministry of Economy, Trade and Industry), 2014a. Strategic energy plan. April. www.enecho.meti.go.jp/en/category/others/basic_ plan/pdf/4th_strategic_energy_plan.pdf (accessed 23 January 2017).

METI (Ministry of Economy, Trade and Industry), 2014b. Sogo Shigen Enerugi Chosakai, Denryoku/Gasu jigyo bunnkakai, Gennsiryoku Shoiinnkai, Houshasei Haikibutsu Waakingu Guruupu, 'Houshasei Haikibutsu WG Chukan Torimatome' [Working group on high-level radioactive waste, interim report]. May. www.meti.go.jp/committee/ sougouenergy/denryoku_gas/genshiryoku/houshasei_haikibutsu_wg/ report_001.pdf (accessed 23 January 2017).

METI (Ministry of Economy, Trade and Industry), 2015a. Basic plan for final disposal of specified radioactive waste. 22 May. 
METI (Ministry of Economy, Trade and Industry), 2015b. Choki Enerugi Jyukyu Mitoshi [Long term energy supply demand outlook]. 7 July. www.meti.go.jp/press/2015/07/20150716004/20150716004_2.pdf (accessed 23 January 2017).

Nihon Keizai Shimbun, 2014. Genpatsu Saikado 'Susumete' 32\%, Honsha Yoron Chosa [Public polling result shows 32\% for restart up of existing nuclear power plants]. 24 August.

Nihon Keizai Shimbun, 2015. Genpatsu no Hatsuden Kosuto 1 wari zo, Keisansho Shisan, Kakaku Yuisei wa Iji [Nuclear power plant cost will be $10 \%$ more expensive than the previous cost estimate, METI says, while its cost competitiveness will remain]. 5 April.

NRA (Nuclear Regulation Authority), 2015. Monbu Kagaku Daijin he no Kankoku [Recommendation to Minister of Education, Sports, Culture and Technology (MEXT)]. 13 November. www.nsr.go.jp/ data/000129633.pdf (accessed 7 September 2017).

Recovery Council, Nuclear Accident Emergency Response Headquarters, 2016. Kikan Konnan Kuiki no Toriatsukai ni Kansuru Kangaekata [Basic thinking on non-return zone]. 31 August. www.meti.go.jp/ earthquake/nuclear/kinkyu/pdf/2016/0831_01.pdf (accessed 23 January 2017).

Science Council of Japan, 2012. Ko Reberu Hoshasei Haikibutsu no Shobun Ni Tsuite [Regarding final disposal of high level radioactive waste: Answers to the Japan Atomic Energy Commission]. 11 September. www.scj.go.jp/ja/info/kohyo/pdf/kohyo-22-k159-1.pdf (accessed 23 January 2017).

Science Council of Japan, 2015. Ko Reberu Hoshasei Haikibutsu no Shobun Ni Kansuru Seisaku Teigen - Kokumin Teki Goi Keisei ni Muketa Zantei Hokan [Policy proposal for final disposal of high-level radioactive waste-temporal storage for gaining national consensus]. 24 April. www.scj.go.jp/ja/info/kohyo/pdf/kohyo-23-t212-1.pdf (accessed 23 January 2017).

Suzuki, Tatsujiro, 2013. Purutoniumu Riyo Keikaku Eno 3tsu no Teian [Japan Atomic Energy Commission magazine 123]. 29 March. www. aec.go.jp/jicst/NC/melmaga/2013-0123.html (accessed 23 January 2017). 
Takubo, Masafumi, and Frank N. von Hippel, 2013. Ending reprocessing in Japan: An alternative approach to managing Japan's spent nuclear fuel and separated plutonium. Research Report No. 12. Princeton, NJ: International Panel on Fissile Material, Program on Science and Global Security, Princeton University.

TEPCO (Tokyo Electric Power Company), 2015. Unit 2 reactor building and large carry-in entrance rooftop accumulated water quality results. 24 February. www4.tepco.co.jp/en/nu/fukushima-np/handouts/2015/ images/handouts_150224_01-e.pdf (accessed 7 September 2017).

TEPCO (Tokyo Electric Power Company) Reform Committee, 2016. Toden Kaikaku Teigen [A recommendation for TEPCO reform]. 20 December. www.meti.go.jp/committee/kenkyukai/energy_ environment/touden_1f/pdf/161220_teigen.pdf (accessed 23 January 2017).

US-Japan Nuclear Working Group, 2014. Statement on shared strategic priorities in the aftermath of the Fukushima nuclear accident. New York: Maureen and Mike Mansfield Foundation. 
This text is taken from Learning from Fukushima: Nuclear power in East Asia, edited by Peter Van Ness and Mel Gurtov, published 2017 by ANU Press, The Australian National University, Canberra, Australia.

dx.doi.org/10.22459/LF.09.2017.01 